\title{
ÖLƯM CEZASI
}

Yazan : Asistan Dr. Hakkı Demirei

GIRIS

Ölüm cezasmın ilgası veya muhafazası meselesi ceza hukukunın en mühim ve en münakaşalı meselelerinden birini teşkil eder. (1) $\mathrm{Biz}$ burada, esas itibariyle, bu mühim mesele hakında ileri sürülen fikir ve mütalâalan hülâsa edip, bunlar dan ölüm cezası hakkında bir netice çıkarmak istiyoruz. Fakat, daha evvel, "ölüm cezasının ilga ve muhafazası hakkındaki münakaşalardan" ve bu münakaşaların tesiri altında (2) "ölüm cezasının tatbik sahasındaki istihaleler" den bahsedelim.

\section{I. ÖLUM CEZASI HAKKINDAKI MUNAKASALAR}

Ölüm cezasının ilga veya muhafazası hakkındaki münakaşalar oldukça eskidir ( $\left.{ }^{3}\right)$. Ölüm cezasına evvelâ orta çağda hristiyanlık vicdanı karşı gelmiştir ( $\left.{ }^{4}\right)$. Filhakika hristiyanlık beşeriyete "merhamet"i ve insan hayatına saygı göstermeyi ögretiyordu (5). Bununla beraber, kefaret esası üzerine müesses olan ( $\left.{ }^{6}\right)$ hristiyan düşüncesi ölüm cezası ile kolayca telif edilebilmiș ve kilise adamlan ölüm cezasını müdafaa etmişlerdir. Hristiyanlık için, o kadar ulvì kanunlar, o kadar mukaddes kıymetler mevcuttur ki bu kanun ve kıymetlere bir tecavüz vaki ólursa,

(1) Bk. Garraud, Traité théorique et pratique du droit pénal français, C. II, 3. basi, n. 482

(2) Karş. P. Bouzat, Traité théorique et pratique de droit pénal, 1951, n. 340

(3) T. Taner, Ceza Hukuku, 1951, s. 589

(4) Osman Nuri Uman, Idam Cezası, Ad. Cer., 1942, s. 344

(5) Charité chrétienne et le respect de la vie dans le Christianisme, hakkında Bk. St. Matthieu, Evangile, Ch. VI.

(6) Hristiyanlıkta kefaret esası ve ilk günah hakkında Bk. St. Paul, Epitres, passim. 
ancak cezalarn en büyüğü bu tecavüzün kefareti olabilir; ölüm cezası nedamet ve dolayısiyle af'a mazhar olmak için şarttır. Nitekim Saint Paul "günahın bedeli ölümdür" demektedir. Hristiyan düşüncesine gö. $r e$, günah işleyen kimse bu günahını affettirmek için ölmekle günahtan kurtulmakta ve böylelikle tekrar Allahın yüzüne bakmağa lâyı bir ha le gelerek yeniden ilâhi aydınlığa kavuşmaktadır. İşte bazı hristiyan müellifleri $\left(^{7}\right)$ tarafından celladın ilâhi adaletin temsilcisi olarak gösterilmesi bu düşüncenin mahsulüdür $(8)$.

Saint Augustin ile Saint Tomas da, suçlunun hayatının bağıs̆lan!masından bir tehlike doğması ihtimali suçlunun islah olması ihtimalinden daha kuvvetli ise ölüm cezasının meşru olacağını söylemektedirler $\left({ }^{9}\right)$.

Ölüm cezasının meşruiyeti meselesini ilk olarak ortaya atanlardan birisi Tomas Morus'tür. Tomas Morus "Utopya veya en iyi Hükûmet şekli" isimli kitabında, daha XVI ıncı asırda, ölüm cezasının suçluları suç işlemekten alıkoymadığını, dolayısiyle faydasız olduğunu ileri sür. müştür (10). Tomas Morus ideal bir cemiyetten bahsederken şöyle demektedir: "Esaret, bu ideal cєmiyette en çok tesadüf edilen cezadır. Zira, bu cemiyetin fertleri, haklı olarak, bu cezanın fena kimseler için ölümden bile daha ağır bir ceza olacağını düşündükleri gibi devlet için de daha faydalı olduğunu düşünmektedirler. Filhakika, en zor işleri yapmağa zorlanan bir insan kendisine hizmet yaptırlan bir kimsedir ve dolayısiyle cemiyete bir kadavradan daha çok faydalıdır" (11).

Fakat Tomas Morus ve onun gibi bir kaçı tarafından ölüm cezasının meşruiyeti hususunda yapılan bu çekingen telmihler, XVI ve XVII inci asırlarda ölüm cezası lehinde ki kuvvetli cereyana karşı gelebilecek kuvvette olmaktan cok ùzaktı. Ölüm cezasının meşruiyeti hakkındaki münakaşalar ası XVIII inci asırda, bu asnn rationaliste ve humanitaire felsefesinin tesiri altında başlamıştır (12). Süphesiz bunda Renaissance ve Réforme'un da tesiri olmuştur. Bilindiği gibi, hümanistler tarafınlétes,

(7) Joseph de Maistre, Les soirées de Saint-Petersbourg, Oeuvres-Comp-

(8) J. Graven, Le problème de la peine de mort et sa réapparition er Suisse, Rev. Crim. Pol. Tech., 1952, s. 8

(9) J. Graven, op. cit., loc. cit., s. 8 den naklen; Karş. Uman, op. cit., loc. cit., s. 344

(10) J. - A. Roux, Cours de droit criminel, C. I, 1927, s. 397

(11) J. Graven, op. cit., loc. cit., s. 9 dan naklen

(12) Bouzat, op. cit., n. 340 ; Uman, op. cit., loc. cit., s. 344 
dan eski yunan metinlerinin tetkik edilmesi neticesinde hristiyan kilisesinin XVI ıncı asır başlarındaki prensipleri ile eski metinlerdeki din prensipleri arasında larklar müşahede edilmiş ve bu hal hümanistleri şüphe ve kritiğe sürüklemiştir (13). Bunun neticesi olarak, o zamana kadar doğruluklarından şüphe edilmeyen bilginlerin yeniden gözden geçirilmesine ihtiyaç hissedilmiş, bu ihtiyaç, ilim, felsefe ve adaletin, orta çağdaki skolastik, siyasî ve hukukî kalıplardan kurtulması ve serbesi tetkik prensibinin hakim olması neticesini doğurmustur (14). Işte bu şüpheci ve tenkidçi zihniyet, ve evvelce doğru olarak kabul edilen hususları serbest tetkik prensibine göre yeniden gözden geçirmek ihtiyacı, XVIII ci asır filozoflarını, diğer bir çok meseleler gibi ölüm cezasının meşruiyeti meselesini de münakaşaya sevketmiştir.

Montesquieu meseleyi ortaya atıp münakaşasını yaptıktan sonra taraftarları arasına geçmiştir (15). Montesquieu'ye göre ölüm cezası, "cemiyeti bir ferdinden mahrum etmiş veya etmeğe teşebbüs etmiş olan bir kimsenin hayatını teminat altına almaktan cemiyetin imtina etınesinden ibaret olan bir nev'i kısastır. Vatandașlann hayatına kastedecek veya kastetmeğe kalkışacak derecede cemiyetin emniyetini tehdit eden kimse ölümü hak etmiştir. Ölüm cezası eşyanın tabıatı muktezasıdır. $\mathrm{Bu}$ ceza hasta cemiyetin ilâcıdır. İlâç acı ve tiksindirici olabilir, fakat lüzumludur" "Bununla beraber Montesquieu cezaların müessir olmalan için muhakkak şiddetli olmalarına lüzum olmadığını, cezalan hafif olan bir cemiyette bu cezalar fertleri ne kadar korkutuyorsa, şid Jetli cezalar vazeden bir cemiyetin fertlerinin de bu siddetli cezalardan ancak o kadar korkacaklarını, çünkü ahalinin kısa bir zamanda şiddetli cezalara alıștığını, tecrübenin de bunun böyle olduğunu gösterdiğini söylemekte ve adalete itidal tavsiye etmektedir: İyi bir kanun koyuce cezalandıracağ ${ }_{1}$ yerde önlemeye, işkence yapacak yerde örf ve âdetler tesisine çalıșmalıdır, demektedir (16).

Montesquieu'den sonra Voltaire de ölüm cezasına temas etmiş ve bu cezanın, hunharca bir ceza olduğu gibi ahlâk bozucu, lüzumsuz ve

(13) Bk. Enver Ziya Karal, Tarih Dersleri, c. III, V० Renaissance.

(14) Kars. J. Graven, op. cit., s. 10 s. 200

(15) Esat Adil Müstecaplıoğlu, Ölüm Cezası, Siyasal Bilgiler, 1937,

(16) Montesquieu'nun fikirleri için Bk. J. Graven, op. cit., loc. cit., s. 10; yine aynı müellifin, Les Conceptions pénales et l'actualité de Montesquieu, Rev. dr. pén. crim., 1949, s. 161 
faydasız bir ceza da olduğunu göstermeye çalışmıştır (17). Voltaire diyor ki: 'Bir kimseyi asmanın kimseye faydası dokunmaz. İyi bir hükûmet cezalan faydalı bir hale getirmelidir. Meselâ suçlulan öldürecek yerde âmme menfaati için çalıştırmak yerinde olur. Suçlulan ürkütmek icab eder ama bunu cezaları faydasız bir hale getirmek bahasina yap. mamalıdır; insanlığa zaran dokunmuş olan kimseyi insanlığa faydası dokunmağa zorlamalıdır. Meselâ "komşusunun zahire ambarını yakan bir kimseyi merasimle diri diri yakmak manasızdır, zira şüphesiz ki bir barça arpa ile bir parça saman bir adamın hayatına değmez. Böyle bir kimseyi, bu kadar ehemmiyetsiz bir şey için böyle zalimâne bir işkence ile öldürecek yerde, evvelâ yaktığı ambarı yeniden inşa için kullanma. $l_{l}$, bundan sonra da zincire vurup kırbaç zoru ile bütün hayatı boyunca cıvardaki bütün ambarlan muhafazaya mecbur etmelidir", Yine meselâ: Bir kalpazan mükemmel bir san'atkardır. Bu sebeble kalp para yapan bir kimseyi, Charles-Quint ve 1 inci François'nın emrettikleri gibi, kaynar su dolu bir kazana atıp öldürecek yerde, ebediyen bir hapishaneye koymalı ve orada Devlet parasının basılmasında kullanmalıdır". Voliaire bu şekilde ölüm cezasının faydasızlığını anlatmaya çalıştıktan sonra, bir gün gelecek belki "cemiyete muzurlu pek çok kimselerin, cemiyete zıyan: kadar faydasının da dokunabileceği takdir edilecektir" demektedir. Rousseau "Içtimai Mukavele" adlì eserinde (kitap II, bölüm 5), insanların içtimai mukaveleyi yaparken, ileride bir katilin kurbanı olmamak için, birini öldürdükleri takdirde kendilerinin öldürülebilmesini kabul ettiklerini" söyledikten sonra (18). nasıl ki harpte karșısındaki düssmanı öldürmek hakkının bahis mevzu'u olabilmesi için onu esir etmek imkânının kalmamış olması lâzımsa, bir kimsenin ölüme mahkûm edilebilmesi de ancak, bu kimsenin öldürülmemesinden bir tehlike doğacak ise, meşru sayılabilir, demektedir. Demek oluyor ki Rousseau'ya göre "eğer cemiyete yeni yeni kurbanlar verdirmemize mâni olmak için yapacak bașka hiç bir şey yoksa ancak o zaman cemiyet sizi ölüme mahkûm :debilir" (19).

Ölüm cezasının ilgası fikri en inandıncı sekilde, Beccaria tarafından müdafaa edilmiștir (20). "Suçlar ve Cezalar" adlı meşhur eserinin ölüm cezasına tahsis ettiği $16 \mathrm{mcı}$ faslında Beccaria, ölüm cezası hak. kındaki essiz iddianamesini, kaleme almıştır. Beccaria burada ölünı

(17) Voltaire'ın ölüm cezası hakkındaki fikirleri için Bk. J. Graven, op. cit., loc. cit., s. 12 ve orada zikredilen eserler.

(18) Uman, op. cit., loc. cit., s. 344

(19) J. Graven, op. cit., loc. cit., s. 13 den naklen

(20) Erem, Adalet Psikolojisi, 1950, s. 216 
cezası lehinde, ilk bakışta insana doğru gibi görünen, delilleri birer bjrer ele alı çürütmektedir. Sanki Beccaria, ölüm cezası lehindeki en kuvvetli delilleri daha o zaman görmüş ve çürütmüştür (21). Beccaria'nın fikirleri, sık sık belirtildiği gibi, o zamanki cemiyetin hislerine ter cüman oluyordu. Nitekim bu fikirlerin mazhar olduğu muazzam rağbeti ancak şu şekilde izah etmek kabildir.

Beccaria, yukanıa sözü geçen kitabında $\left({ }^{22}\right)$, “asla insanlan daha iyi bir hale getirmemiş ölüm cezasının geniş tatbikatını görünce, iyi teşkilâtlanmış bir devlette bu cezanın hakikaten faydalı ve adilâne olup olmadığının tetkikine sürüklendim" demek suretiyle meseleyi tetkik lüzumunu izah ettikten sonra, problemi şu şekilde vazetmektedir: "Acaba insanlara hem cins!erini boğazlamak hakkı nereden gelebiliyor"?

Yukarıda Rousseau'nun ölüm cezasını "içtimai mukavele" ile izah ettiğini ve insanların ileride bir katilin kurban olmamak için, birini öl. dürdükleri takdirde kendilerinin de öldürülebilmelerini kabul ettiklerini, söylediğini görmüştük. Beccaria, beşeriyetin șükran borçlu bulunduğu filozof olarak vassflandırdığı (23) Rousseau'nun fikrinde değildir: "Elbetteki insanların hemcinslerini boğazlamak hakkı kanunlanın dayandığı temelden doğmuyor... Kanunlar her ferdin cemiyete terkettiği hür. riyet haklarından pek cüz'i bir kısmınm mecmu'undan ibarettir... Fert. ler tarafından cemiyete bağışlanan bu cüz'i hürriyet hakları içinde, nimetlerin en büyüğü olan "hayat"ı yok etmek hakkı nasıl bulunabilir? Insanın kendi kendini yok etmek hakkına sahip olmadiğı kabul edilince kendi hayatına nihayet vermek hakkını diğer bir ferde ve hatta cemiye. te devretmis olabileceği nasıl kabul edilebilir? $O$ halde, bir ferde, diğe: bir ferdin havatına son vermek hakkını kim vermiş olabilir? Görülüyor $\mathrm{ki}$, bir fert tarafndan diğer bir ferdin hayatma son verilmesi bir hak olamaz; başka bir ifade ile, ölüm cezası hic bir hukukî esastan neş'et etmis değildir. Bu müessese o'sa olsa, ferdin ifnası cemiyetin muhafazası için faydalı ve zarurî görülmesi bakımindan, bir milletin topyekûn o ferd:? karşı açtı̆̆ bir savaştan ibarettir" (24).

(21) Fransa'da ölüm cezasının ilgası hakkındaki 1906 tarihli kanun tasarısının mucip sebebler lâyihasından - J. Graven, op. cit., loc. cit., s. 14 den naklen.

(22) Türkçe tercümesi: Dr. Muhittin Göklü, İstanbul 1950, s. 225-242

(23) Bk. J. Graven, op. cit., loc. cit., s. 12

(24) Beccaria, op. cit., s. 225-227 
Böylece, Ölüm cezasının, hiç bir hukukî temeli bulunmadığını, olsa olsa, bazen, ferdin vücudunun ortadan kaldırılmasının cemiyetin muhsfaza ve müdafaası için faydalı olacağ lecek- bir mülâhazaya istinad edebileceğini gösterdikten sonra, Bieccaria, bu cezanın, normal ahvalde, cemiyet için, zarurî ve faydalı da olmadığını göstermeğe çalışmakta ve hiç bir hukukî esası ve pratik faydası bulunmayan bu müessesenin ilga edilmesi lüzumunu ileri sürmektedir $(25)$

Beccaria'nın ölüm cezası hakkındaki fikirleri, kendi asn olan XVIII inci asrn insanî felsefesine ve oradan da bütün müstakbel asırlara tesir etmiştir (26). Fransa'da, ansiklopedistler, Ingiltere'de Bentham ve Romylly, Amerika'da, Franklin, Beccaria'nın fikirlerini benimsediler (27). Beccaria'nın XVIII inci asırdaki tesiri o kadar büyük olmuştur ki Fransız in. tilâli çımasa idi, Beccaria'nın fikirlerinin tesiri ile, Avrupa devletlerinden pek çoğunda ölüm cezasının ilga edilmesi beklenebilirdi $\left({ }^{28}\right)$. Fakat Fransız lhtilâlcileri, eski rejimin izlerini tamamen yok etmek arzusu ile, ölüm cezasını kesretle tatbik etmişlerdir. Ihtilâli yapanlar, ölüm cęza. sına taraftar ọmamakla beraber (29), başlangıçta, bu cezayı zarưi gö rüyorlard. Nitekim 4 brumaire, sene IV tarihli bir kanunun 1 inci mad. desinde "umumî sulhun teessüsünden itibaren, Fransız Cumhuriyetinde ölüm cezasını ilga edileceği" hüküm altına alınmış buluņuyordu. Rousseau ve Beccaria'nın ve umumiyetle XVIII inci asnn rasyonalist ve hümanitaire felsefesinin tesiri altında bulunan ihtilâl kanun vazı, kanunlara riayeti temin ve cemiyetin müdafaası için ölüm cezasını zaruni görmzkle beraber, her türlü işkenceyi kaldırarak, ölüm cezasını hayatın izalesine inhisar ettirmiş ve mahkûmun, mümkün mertebe, acı çekmemesine çalışış, asma yerine, ondan daha çabuk öldürdüğü ve daha az zalimane olduğu mülâhazası ile $\left({ }^{30}\right)$, Guillottine'i ikame etmiştir. Hemen işaret edelim ki, ölüm cezası mahkûmun, mümkün olduğu kadar, acı çekmeden öldürülmesi fikri, ölüm cezasının ilgası fikri ile yakından ilgilidir. Mahkûmun acı çekmeden öldürülmesi yolundaki temayüle, kapıdan kovulan ölüm cezasının ilgası fikrinin pencereden girmesi olduğu gözüyle bakılabilir. İhtilâl bitip te sulh avdel ettikten sonra, ölüm cezasının meş-

(25) Bk. Beccaria, op. cit., s. 227-242

(26) Beccaria, op. cit., s. 242, Mütercimin notu.

(27) J. Graven, op. cit., loc. cit., s. 14 in fine

(28) J. Graven, op. cit., loc. cit., s. 15

(29) Robespierre Marat, gibi Fransiz İhtilâlinin en kanlı si:naları bile. 18 inci asrin humanitaire felsefesine uygun olarak birer ölüm cezası aleyhtar idi (Bk. J. Graven, op. cit., loc. cit., s. 15, ibidem not 31).

(30) J. Graven, op. cit., loc. cit., s. 16 
ruiyeti ve kaldırılması icap edip etmediği hakkındaki münakaşalar yeniden baş göstermekte gecikmedi. 1826 da, Cenevre Temsilî Konseyi azalarndan ve ölüm cezasınn ilgasının hararetli taraftarlarından Jean-Jac. ques de Sellon tarafindan, "ölüm cezasının ilgası meselesi" konulu hir müsabaka tertip edildi. Müsabakaya katılan 31 eser arasından, Paris Kraliyet Mahkemesi avukatlanndan Ch. Lucas'in eseri birinciliği kazand. Lucas, bu eserinde, cinayetlerin önlenmesi için en iyi çarenin, maddî re fahın artıp yayılması ve kültür seviyesinin yükselmesi, en tesirli ceza sisteminin ise, en şiddetli cezalan ihtiva eden ceza sisteminin değil, mutedil ve fakat, her suç işleyenin mutlaka ceza göreceğini telkin edebilen ceza sisteminin olduğu neticesine varmakta ve bu iki husus için de, yani suçlarn önlenmesi ve işlenmiş olan suçların müessir bir şekilde tecziye edilebilmesi için ilk yapılacak şeyin, bir infaz rejiminin tesbiti ile ölüm cezasının ilga edilmesi olduğunu söylemektedir (31).

Ölüm cezasının meşruiyeti meselesini münakaşa edenler arasında Rossi de vardır. Rossi'ye göre "içtimai adaletin temini bir vazifedir. Ce$\mathbf{z a}$, bu vazifenin ifası için baş vurulan vasıtalardan biridir, binnetice meș. rudur $\left({ }^{2}\right)$. Ölüm cezasının da, içtimai adaletin teminine ve cemiyet ni. zamını muhafazasına yardım ettiği, bazı kimseleri adam öldürmekten, ancak, adam öldüren kimsenin öldürülmesinin men'edebileceği kabıl edilecek olursa artık ölüm cezasının meşru olmadığından bahsedilebilir mi?" (33). Rossi'ye göre, diğer cezalardan farklı olarak ölüm cezasında mevcut olup onu gayn meşru ve gayri ahlâki yapan bir vasif mevcut $d$. ğildir. Bununla beraber Rossi, Lucas'in, Jean-Jacques de Sellon tarafından ölüm cezasının ilgası meselesi hakkında tertip edilmiş olan müszbakada kazanan eseri münasebetiyle şöyle söylemektedir: "Ölüm cezas"nın mesruiyeti meselesinin, bu meselenin icab ettirdiği vüsatta ve gerekli vukufla tetkik edilmiş olması bizi samimî surette memnun etti... Her ne kadar müellifin bütün fikirlerini paylaşmyor isek te, eserine, ilme ve insaniyete yapılmıṣ büyük bir hizmet gözüyle bakıyoruz. Bugüne kadar Avrupa memleket'erinin hepsinde ölüm cezası suistimal edilmiş ve ha. len de edilmektedir. Kanun kuvvetinin bu suistimaline şiddetle ve ciłdiyetle dikkati çekmenin sırası gelmiş bulunuyordu. Bugün artık her cıdJi münakasan'n er geç meyvelerini verdiği bir zamanda yaşıyoruz. $\mathrm{Bu} \mathbf{i}_{1}$. barla, darağcının tamamiyle ortadan kalkacağı zamanlar henüz gelmiş olmasa bile, ölüm cezasının pek nadir olarak tatbik edileceği ve böyle-

(31) J. Graven, op. cit., loc. cit., s. 23 den naklen

(32) B. Müstecaplığlu, op. cit., loc. cit., s. 202 den naklen

(33) Bk. J. Graven, op. cit., loc. cit., s. 27 den naklen 
likle, faydasızlığının artık münakaşa mevzu'u olmaktan çıkacağı zamanlann 'gecikmiyeceqini ümid edebilinz"' (34).

Ölüm cezasının aleyhinde olanlar arasında Lamartine de vardır. Lamartine, Comte de Sellon tarafindan tertip edilen müsabakaya işairak etmiş ve ölüm cezasının ilgası lüzumunu Fransız Mebuslar Meclisinde şiddetle müdafaa etmiştir. Lamartine, ölüm cezasının lüzumsuzluğunu be. lirtmek için, ölümden korkmanın değil, hayata saygı göstermenin bilinmesinin ehemmiyetli olduğunu söyledikten ( ${ }^{35}$ ) sonra ölüm cezasinın ilgası icab ettiğini şu şekilde izah etmektedir: "Daha fazla tereddüt etmeksizin, halk tarafından ölüm cezasina karşı duyulan ve, darağaçlan nın, şehrin ortasındaki meydanlardan en ücra dış mahallelere itilip atıl. ması şeklinde kendini gösteren, nefrete, Jürilerin, vicdanen tasvip etrnedikleri ölüm cezasına, kanunun hükmettiğini de kabul etmek istememeleri keyfiyetine yer vermenin zamanı artık gelmiş bulunmaktadır... Cemiyetle, cani, ilânihaye, birbirlerine "evvelâ kan dökmeyi sen kes te sonra ben keseyim" deyip mi duracaklardır... Çekinmeyelim: evvelâ biz duralım. Cemiyetin kilit taşı, "ölüm” olamaz. Cemiyetin kilit taşı kanunlann âdil olmasıdır... Ölümü, adaletin bir doğması, darağacını, adaletin icra edildiği yer ve celladı adaleti icra eden bir kimse olmaktan çkarmak lâzımdır... Adaletin son sözü, nasıl olur da "ölüm" olabilir? ( $\left.{ }^{36}\right)$.

Bu şekilde, XIX uncu asırda, gerek edebiyatta, gerekse ceza doktrininde, ölüm cezası aleyhinde kuvvetli bir cereyan baş göstermiştir. Filhakika, XIXasir boyunca Victor Hugo, George Sand, Eugéne Sue, Livingston, Mittermaier, Pessina, Mancini, Bédaridde, Haus, Bonnet, ve Olivecrona gibi, romancı, mütefekkir ve cezacılar cemiyetin ölüm cezası vermek gibi bir hak ve selâhiyeti olduğunu inkâr ettiler ve böyle bir iddianın ne kadar yanlı̧ bir iddia olacağını göstermeğe çalıştılar ( ${ }^{37}$ ). Bu hısusta, bu müellifler yalnız bir takım felsefî ve hukukî mülâhazalara istinat etmemişler, fikirlerini, bazı hissi mülâhazalarla da takviye etmişlerdir. Meselâ Hugo'nun ölüm cezası hakkındaki sözleri, bir sosyolog veya kriminalist'in fikirleri olmaktan ziyade, bir edebiyatçı ve bir şaire yakışan düşüncelerdir. Hugo şöyle diyor: "Tekne, tek bir adamın vücudu fazla gelecek kadar mı tehlikededir? Pişman olmuş bir suçlu, Allah'ın bu zavallı mablûku, cemiyet için o kadar ặır bir yük müdür ki onu kaldınp uçurumun karanlıklanna frrlatmakta tereddüt etmiyoruz. Cinayet, balt»

(34) J. Graven, op. cit., loc. cit., s. 27, not 57 den naklen

(35) J. Graven, op. cit., loc. cit., s. 28 den naklen

(36) J. Graven, op. cit., loc. cit., s. 28 den naklen

(37) Kars. Müstecaplığlu, op. cit., loc. cit., s, 200 
ve ilmikle değil, vicdan azabiyle telâfi edilebilir; kanı kan değil, göz yaş. lan yıkıyabilir... Cellat adaletin değıl, adaletsizlik ve dehşetin timsalidi:: Guillotine deyince daima Lesurques, yakmak deyince daima Jeanne d'Arc, işkence deyince Campanelle, baldıran deyince Sokrat, çarnuh deyince de daima İsa hatıra gelecektir" (38).

Hülâsa, XIX uncu asırda ölüm cezasının ilgası bütün aydınların müş terek bir temennisi haline gelmiş ve bunun neticesi olarak ta ölüm cezasl, hukuken ve hiç değilse fïlen her tarafta ortadan kalkmaya başlamıştır. Cezacılar, bu sırada, ölüm cezasına, işkence, esaret ve saire müesse. seler gibi, tarihe kanşmak üzere bulunan bir müessese gözüyle bakıyor. lardı (39).

Fakat ölüm cezasının ilgası lehindeki bu cereyan, XIX uncu asrın sonlanında duraklamıs, ve hatta, yerini, bilhassa bazı suçlar için, ceralann ağırlaștınıması icab ettiği fikrine bırakmıştır ${ }^{(40)}$. Bu değişiklikte, muhtelif bilim kollarında varilan neticelerle Darwin nazariyesinin tesiri olmuștur $\left({ }^{+1}\right)$. Tecrübî ilimlerin, antropoloji, etnoğrafya, sosyoloji ve istatistiğin inkişafı ve Darwin ve pozitivistlerin nazariyelerinin tesiri ile ölüm cezasının leh ve aleyhinde bir takım hissi ve nazarì mütalâalar ileri sürülmektę vazgeçilmiş, ve mesele cemiyetin müdafaası bakımında ölüm cezasının uygun olup olmadığının tetkiki gibi pratik ve realist bıı sahaya intikâl ettirilmiştir ( ${ }^{42}$ ). Darwin'in istıfa nazariyesi ve cemiyete intibak etmeyenlere karşı cemiyetin korunması fikri ile ölüm cezası arasında bir yakınlık müșahede edilmiştir. Diğer taraftan, yeni yeni doğmak ta olan cinaî istatistik ilmi sayesinde suçlarda müşahede edilen arış, cezanın kifayetsizliğine atfedilmiş ${ }^{(43)}$ ve böylece, cezaların kifayetsizli.

(38) J. Graven, op. cit., loc., cit., s. 30 dan naklen

(39) Bk. Garraud, Traité théorique et pratique du Droit Pénal françats, 1888, C. I, s. 132.

(40) J. Graven, op. cit., loc. cit., s. 33

(41) J. Graven, ibidem.

(42) J. Graven, op. cit., loc., cit., s. 33; Karş. Kunter, Ölüm cezası ilga edilmeli mi, edilmemeli mi?, Cumhuriyet Gazetesi, 21.2.955: "(Ölüm cezasının) meşruiyeti meselesi kanaatimizce münakaşa götürmez. Cemiyet kendini mü dafaa için, müdafaayı temin edecek her hangi bir tedbiri almak hakkına ma liktir".

(43) Bk., meselâ, Gustave Le Bon, La question des criminels, Rev. dı Philosophie, 1881, s. 535; G. Crison, Souvenirs de la place de la Raquette, Pa. ris 1883; Lacassagne, La peine de mort et la criminalité, Paris 1908 
ği neticesinde suçlarda vukubulduğu kabul edilen bu artsştan ölüm cezası lehinde neticeler çıkarılmağa başlanmıştır (44).

Bilindiği gibi, Pozitivist mektep, Lombozonun çalışmalarına istinat ederek, "doğuştan suçlu" mefhumunu kabul etmiş ve suçlulan, itiyat ve tesadüf suçlusu olmak üzere ikiye ayırarak, Ceza Hukukunda, manevi mes'uliyet ve kefaret mefhumlarının yerine, suçlunun "tehlikelilik hali" ni ve, buna karşı "cemiyetin korunması" mefhumlanını ikame etmiştir. Bu esaslar ise, farkına varılmış olacağı gibi,, ölüm cezasını, o zamana kadar olduğundan tamamen başka bir zaviyeden mütalâaya sevk edecek mahiyette idi. Filhakika, hareket mebde'i olarak "cemiyetin müdafaası" mefhumu kabul edilince, artık ekseriya hissi mülâhazalara müncer olan veya böyle mülâhazaların tesiriyle ileri sürülen fikirlerden sarfinazar etmek kâbil olmakta ve mesele müsbet bir şekilde tetkik edilebilmektedir (45). Cezanın tek gayesi cemiyetin müdafaası olduğuna göre, mesele ölüm cezasının cemiyetin müdafaasına hizmet edip etmediğinin tetkikine müncer olmaktadır (46). Mesele, bu şekilde mütalâa olununca ve, diğer taraftan, doğuştan suçlu, diye bir gurup suçlu kabul edilince, hiç değilse bu gurup suçlulara karşı, cemiyeti müdafaa için en iyi çarenin ölüm cezası olup olmadığı suali hatıra gelmektedir $\left({ }^{(7)}\right)$.

Işte ölüm cezasının ilgası veya muhafazası hakkındaki münakaşalar bugün böyle müsbet bir sahaya intikal etmiş bulunmaktadır. Bugün artık, ölüm cezasının meşru olup olmadığı hakkında felsefì münakaşalardan vazgeçilmiş, bu cezanın, cemiyetin müdafaası için faydalı ve lü. zumlu olup olmadığı araştınlmağa başlanmıştır.

\section{II. ÖLUM CEZASINI TATBIK SAHASINDA VUKU BULAN ISTIHALELER}

$\mathrm{Bu}$ şekilde, ölüm cezasının ilga edilmesi gerekip gerekmediği hakkında ki münakaşalara kısaca bir göz gezdirmiş bulunuyoruz. Bu müna. kaşalara muvazi olarak, ölüm cezasının tatbik sahası ve infaz șekli de is tihaleler geçirmiștir.

Ceza hukukunun tarihçesine göz atılırsa, ölüm cezasının ilk devirlerde en fazla tatbik edilen ceza olduğu görülür (48). Eskiden, zamanın telâkkilerine göre ağır sayılan bütün suçların cezasını ölüm cezası teşkil

(44) Bk. J. Graven, op. cit., loc. cit., s. 33

(45) Karş. Ferri, J. Graven, op. cit., loc. cit., s. 36 dan naklen

(46) Kars. Kunter, op. cit., loc. cit,,

(47) Karş. J. Graven, op. cit., loc. cit., s. 36

(48) Bk. Graven, Op. cit.; s. 4. 
ediyordu ve bu ceza, yakmak, suda boğmak, çarmiha germek, asmak, linç etmek, yüksek bir kayadan aşağı atmak, atlara hayvanlara parçalatmak, ve ilh.. gibi, pek çok çeşitler arzediyordu ( ${ }^{49}$ ). İlk devirlerde ekseri suçların cezasını ölüm cezasının teşkil etmesi ve ölüm cezasının, sııç işleyenlere verilen normal bir ceza saylmasının sebebi, bu devirlerde, "yapılmıs olan bir fenalığın ancak kan akıtılmak suretiyle telâfi edilebileceğ " kanaati ile, "kanı ancak yine kanın temizliyebileceği" yolund.a

bir kanaatin mevcudiyetidir (50). Bu kanaat ve telâkkilerin tesiriyle ölüm cezası, yakın zamana kadar, o kadar tabii bir ceza olarak kabul edilmek te idi ki, Voltaire, ceza kanunlanndan bahsederken, bunlann, cellat tarafından ve insan kanı ile yazılmıs kanunlar olduğunu söylemektedir $\left({ }^{4}\right)$. Filhakika, eski devirlerde, muhtelif şekillerde işkence yapmak suretiyle infaz edilen ölüm cezalarının sayısı muazzam rakkamlan bulmaktadir.

Bu rakkamlar hakkında bir fikir verebilecek mahiyette olarak, Roma Imparatorlarından Claude'un, yalnız eğlencelerinden biri münasebetiyle, Romaya 19.000 idam mahkûmunu getirterek öldürtmesi ve yine Kral Agnppa'nın, böyle bir münasebetle, 14.000 idam mahkûmunu birden infaz ettirmesi, zikredilebilir (52). Orta çağda da ölüm cezası genis ölçüde tatbik edilmiştir. İspanyada "inguisition" zûlmu, bir ara o derece geniş bir surette tatbik edilmeye başlanmıştır ki Papa X. Leon, İspanyol inguisiteur'lerini afaroz etmek mecburiyetinde kalmıştır (53). Almanyada ise, 17 inci asırda, tek bir ceza yargıcının ölüme mahkûm ettiğ: kimselerin sayısı 20.000 i geçiyordu (54). 18 inci asırda Bavyeranın bir tek district'inde 1748 ile 1776 arasında infaz edilen ölüm cezalannın sayısı 1.100 ü buluyordu (55). Orta çağda Avrupanın diğer memleketlerinde de durum ayni idi: $16 \mathrm{ncs}$ asurda, Hollandada, sadece Duc d'Albe'in ölüme mahkûm ettiği kimselerin sayısı 18.600 idi (56).

Medeniyet ilerledikçe, ölüm cezasının tatbik sahası da daralmıştır (57). Medeniyet derece derece bu cezanın tatbikini azaltmıștır (58).

(49) Bk. Erem. Adalet psikolojisi, 1950, s. 216

(50) Graven. Op. cit., loc. cit., s. 6

(51) Graven. Op. cit. loc. cit. s. 6. dan naklen

(52) Bk. Graven, Loc. cit.

(53) Graven, Op. cit., s. 6

(54) Bk. Graven, Op. cit., loc. cit., s. 6

(55) Graven, loc. cit.

(56) Graven, loc. cit.

(57) Bk. Jean Cruppi le temps du 24 octobre 1907, Graven, Op. cit. loc. cit. s. 40 , dan naklen

(58) Osman Nuri Uman, Op. cit., loc., cit., s. 344 
Ölüm cezası ilk defa, 18 inci asnn humanitaire felsefesinin tesiri ile, 1744 te Rus Imparatoriçesi Elizabet tarafindan kaldırılmış ve fakat kısa bir müddet sonra, 1864 te 2 inci Katerina tarafindan yeniden tesis edilmiştir (59). Bundan sonra, yine kısa birer müddet için, 1786 da Toskanada, 1787 de de Avusturyada ilga edilmiştir (60). Daha evvelce de işaret ettiğimiz gibi, bu sıralarda Fransız ihtilâli patlamış ve bu ihtilâl ölüm cezasının kesretle tatbik edilmesini intaç etmiş olmasa idi, ayni felseî́ cereyanın ve bilhassa Bleccaria'nm fikirlerinin tesiri ile, daha bir çok Avrupa memleketlerinde de, bu sıralarda, ölüm cezasının ilgası beklene’jlirdi.

Bununla beraber, yukanda gördüğümüz şekilde, 18 inci asırda ölüm cezası aleyhinde başgöstermiş olan kuvvetli cereyan yine de tesirin: göstermekten geri kalmamış, 18 inci asırdan itibaren ölüm cezasının tatbik sahası gittikçe daralmıştır:

1 - Bazı memleketlerde ölüm cezası tamamen kaldınlmıs, kaldınlmıyan memleketlerde de, ilgası yolunda müteaddit teşebbüsler yapılmıstrr;

2 - Ölüm cezasını muhafaza eden memleketlerde bu cezayı müstelzim hallerin adedi azalmış, bir kaç hale inhisar etmiştir;

3 - Ve nihayet, ölüm cezası, muhafaza edildiği hallerde de, tatbik edilmez olmuştur.

1 - Tarih sırasiyle, 1847 de, şimalî Amerika devletlerinden Michigan, 1852 ve 1853 te, yine şimalî Amerikada Rhode-İsland ve Wiscousin, 1854 te Isviçrenin Neuchâtel kantonu, 1859 da Toskana, 1862 de Yunanistan, 1863 te Romanya, 1864 te Venezuella, 1867 de Portekiz, 1868 de Saksonya, 1869 da Isviçrenin Zurich kantonu, 1870 te Hollanda, 1871 de Isviçrenin Tessin ve Cenevre kantonlan, 1872-1873 te Bâle kantonu, 1874 te Soleure kantonu, ve onu takiben 20 Mayıs 1874 tarihli Isviçre federal esas teşkilât kanunu, 1876 da şimali Amerika devletlerinden Maine, 1880 de Costa-Rica, 1889 da Italya ve Guatemala, 1890 da Brezilya, 1892 de Nicaragua, 1894 de Honduras, 1902 de Norveç, 1921 de Isveç, 1922 de Avusturyanın Queensland eyaleti (61) 1930 da Danimarka, 1932 de Ispanya ve 1941 de

(59) Bk. Rev. sci. crim. 10, 47, s. 461

(60) Bk. Graven, Op. cit., loc. cit., s. $14^{\circ}$

(61) Bk. Graven. Op. cit., loc., cit., s. 31 ve M. Göklü, Beccaria, suçlar ve cezalar, tercümesi, S. $244^{\circ}$ 
de Yeni Zelânda ölüm cezasını ilga etmişlerdir (62) 20 Mayıs 1874 tarihli İsviçre federal esas teşkilât kanunu idam cezasını kaldırdık$\tan$ sonra 1879 tarihli esas teşkilât kanunu bu hususta her kantonu ser. best bırakmış, ve fakat bundan sonrada 21.12.1937 tarihli İsviçre federal ceza kanunu bütün İsviçrede ölüm cezas.n yeniden kaldırmıștır (6i3) İtalyada da, ölüm cezası 1899 tarihli ceza kanunu ilga edildikten sonra 25.10.1925 tarihli bir kanunla, siyasî suçlar için ve 1930 tarihli ceza kanunu ile de bazı adi suçlar hakkında tekrar kabul edilmis isede, ikinci cihan harbinden sonra, 27 Ocak 1947 tarihli İtalyan esas teşkilât ka. nunu ile, harp zamanlan için askerî kanunlar tarafından vazedilecek ölüm cezaları müstesna, yeniden ilga edilmiştir (64). Yine Brezilyada da, ölüm cezası, 1937 tarihli esas teşkilât kanununda, bazı hususî haller için ve bilhassa suikast fiilleri hakkında yeniden kabul edilmis iken, 1942 de yürürlüğe giren, 1940 tarihli Brezilya ceza kanunu bu cezayı tekrar cezalar listesinden kaldırmıs, ve 1946 tarihli Brezilya esas teşkilât kanunu da, harp zamanlan için askerî kanunlarda derpiş edilecek haller d:şında kimseye ölüm cezası verilmeyeceğini beyan etmiştir (65). Rusyada 1917 de, Muvakkat hükûmet tarafından ölüm cezası ilga edilmiş ise de bu pek kısa sürmüş ve ihtilâl sırasında ölüm cezası Rusyada yeniden kabul edilmiştir ( ${ }^{(66)}$. 1922 tarihli Sovyet Rusya ceza kanunu ile 1924 tarihli Sovyet anayasası ölüm cezasını ihtiva etmemekle bera. ber, bu ceza, 1947 ye kadar Sovyet Rusya mevzuatında, Devlet veya onu idare edenlerin emniyetini ihlâl eden haller için (67) başvurulacak "Istisnaî bir tedbir" olarak kalmıştır. 1947 de merkez icra komitesinin bir kararnamesi ile ölüm cezası Rusyada tekrar ilga edilmisse de (68) 1950 de siyasî suçlar için (69) 1951 de de bazı adi suçlar için (70) tekrar kabul edilmiştir.

Yukanda sayılan memleketlerden başka bazı memleketlerde de ölüm cezasının ilgasına teşebbüs edilmiş ve bu memleketlerde bu hususta yaplan teklifler ekseriya uzun münakaşalar neticesinde ve ancak az b:

(62) Bk. Rev. Sci. crim., 1938, s. 176

(63) Bk. M. Göklü, s. 6. tercüme, s. 244

(64) Bk. Rev. Crim. 1948, s. 386, yine Bk. M. Göklü, s. 6, Tercüme, s. 244

(65) Bk. Rev. Sci. Crim., 1948, s. 386

(66) Bk. Rev. Sci. Crim., 1947, s. 462

(67) Devletin emniyeti mevhumuna ne gibi hallerin dahil olduğu hakkın-

da, Bk. Rev. Sci. Crim., 1947, s. 462

(68) Bak. Rev. Sci. Crim., 1947, s. 461

(69) Bk. Rev. Sci. Crim, 1954, s. 408

(71) Bk. Graven, Op. cit., loc., cit., s. 31 
çoğunlukla reddedilmiştir. Filhakika, 1856 da İngilterede, 1851 ve 1867 de Belçikada, 1867, 1870, 1881, 1885, 1888 ve 1906 da Fransada, 1870 de Almanyada ölüm cezasının kaldırılması teklif edilmiş, bunlar. dan 1867 de Blelçikada yapılan ilga teklifi ancak 43 e karşı 55 oyla red. dedilmiş, 1870 de Almanyada yapılan ilga teşebbüsü ise sırf Bismark'ın enerjik müdahalesi dolayısile neticesiz kalmıştır (71). Son defa, 1948 de, Ingilterede, Avam Kamarası, ölüm cezasınm 5 senelik bir müddet için kaldırılmasını karar altına almış ise de bu karar Lordlar Kamarası tarafından geri çevrilmiştir ( $\left.{ }^{72}\right)$.

Ölüm cezasının, muhtelif memleketlerin mevzuatı bakımından, bu günkü durumunu şöylece tesbit edebiliriz: Bugün Avrupada 8 memlekette ölüm cezası ilga edilmiş bulunmaktadır: $\mathrm{Bu}$ memleketler, Danimarka, İlanda, Norveç, Portekiz, Romanya (1946 dan beri), İsveç, İsviçre, İtalyadır. Belçika, Finlandiya ve Hollandada ise ölüm cezası hukuken ilga edilmemiş olmakla beraber, artık tatbik edilmemektedir. Filhak kàa, bu memleketlerde, harp sirasında düşmanla işbirliği yapanlar bir tarafa bırakılırsa, bir asırdan fazla bir zamandan beri ölüm cezası tatbik edilmemektedir (73). Rusyada da, yukanda söylediğimiz gibi siyasi suçlar bir tarafa bırakılacak olursa, hukuku adiye suçlan hakkında, ölüm cezası tatbik edilmemektedir.

İspanya ve Avusturyada demokratik rejimler sırasında ilga edilmiş bulunan ölüm cezası sonradan bu memleketlerde kurulan otoritaire' $r \varepsilon$ jimler sırasında yeniden kabul edilmiştir (74). Amerikaya gelince, bu kıta devletlerind:en çoğunda ölüm cezası ilga edilmiş bulunmaktadır. Arjantin, Brezilya, Kolombiya, Kosta-Rica, Küba, Ekvator, Peru, Surinam, Uruguay ve Venezuella ölüm cezasını kaldırmışlardır. Bunlardan Ekva: tor ve Uruguayde, ölüm cezası, mutlak olarak, her türlü fiiller için ilga edilmiş bulunmaktadır. Meksika Devletlerinden coğunda ve Amerika Birleşik Devletlerinden altısinda, hukuku adiyeye müteallik fiiller için ölüm cezası kaldırilmıştır (75).

2 - Yukanda ölüm cezasını kanunlarından tamamen kaldıran Dev. letler yan nda, bir kısım devletlerin de, zamanla bu cezanın tatbik sahasını daraltmıs olduklanını söylemiştik:

(72) Bk. Rev. Sci. Crim., 1948

(73) Bk. Rev. Sci. Crim., 1949, s. 181.

(74) Bk. Rev. Sci. Crim., 1949, ss. 181

(75) Bk. Rev. Sci. Crim., 1949, s. 181 
1871 tarihli Fransız ceza kanunu ölüm cezasın müstelzim hallerin sayısını 115 ten 32 ye indirmiştir ( $\left.{ }^{76}\right) .1815$ tarihli ceza kanununda bu adet 36 ya çımışsada, bu tarihten sonra Fransada ölüm cezasını müscelzim suçların adedi daimî bir azalma göstermiştir. 28 Nisan 1832 tarihli kanun, kalpazanlık ve mevsuf hırsızlık halleri gibi, 1810 tarihli ceza kanununun ölüm cezası vazeylediği 9 halde ölüm cezasını kaldınp yerine başka cezalar koymuştur. Ayni kanunla jürilere tahfif edici sebebleri de takdir ve irae selâhiyeti de tanınmıştır. 1848 tarihli Fransız anayasası da, Gizot'nun tesiriyle, siyasî suçlar hakkında ölüm cezasını ilga etmiştir. 21 kânunuevvel 1901 tarihli kanun, yeni doğmuş çocuğunu öldüren ana hakkında vazedilmiş bulunan ölüm cezasını kaldırmıştır. Nihdyet 1 Eylül 1941 tarihli bir kanunla da yeni doğmuş çocuğun öldürülmesi halinde ölüm cezası tamamen kaldırılmak suretiyle, Fransız ceza kanınunda ölüm cezasını müstelzim hallerin sayısı 8 e kadar inmiştir (i7).

Almanyada, yukarıda gördüğümüz gibi, ölüm cezasının pek az bir ekserıyetle ve ancak Bismark'n enerjik müdahalesi neticesinde muhafa. zasma karar verildikten sonra Alman ceza kanunu bu cezanın tatbikini 4 hale inhisar ettirmiş ve, taammüden katil, suikast, patlayıcı maddeler istimali ve esir ticareti dolayısiyle bir kimsenin ölümüne sebeb olmaistan ibaret bulunan bu dört halde de, ölüm cezası ile insanın hayatınun korunması hedef tutulmuştur.

Ingilterede de, ölüm cezasını müstelzim hallerin adedi 4 ü geç:nemektedir. Bunlar, vatan hainliği, bazı korsanlık filleri, gemi veya limanlarda kasden yangın çikartmak ve taammüden katil halleridir. Bunun!a beraber, İngilterede bugün fiilen ölüm cezasının tatbik edildiği bir tek hal kalmıştır ki o da yukarıda saydığımız hallerden sonuncusu yani. taammüden katildir. 1820 den 1916 ya kadar, hiyanet suçu dolayısiyle 19 kişi ölüme mahkûm edilmiş olmakla beraber bunlardan hiç biri hakkında bu ceza infaz edilmemiş, haklannda hükmolunan ölüm cezası bașka cezalara tahvil edilmiștir (78).

3) Bir kısım memleketlerde ceza kanunlannda ölüm cezasını kabul ettikleri halde, fiilen bu cezayıı kaldırmış bulunmaktadırlar. Meselâ 186 ? tarihli Be!çika ceza kanununda ölüm cezası mevcut olmasına rağmen 1862 tarihinden beri - harpte düşmanla işbirliği yapanlar hakkında hük-

(76) Bk. M. Köklü S.G. Tercüme, s. 243; Bouzat Op. cit., No. 340

(77) Bk. Bouzat, Op. cit., s. 262; M. Köklü, s. 9. Tercüme, s. 243.

(78) Bk. Kenny, Esquisse du droit Criminel anglais, s. 608

(79) Bk. Rev. Svi. Crim., 1953, s. ; M. Köklü, S.G., tercüme, s. 245 
molunup infaz edilen ölüm cezalan müstesna - bu memlekette hiç bir ölüm cezası infaz edilmemiştir ( $\left.{ }^{79}\right)$. Yine, Finlandiya ve Danimarkada da ölüm cezası, ceza kanunlarında yer almakla beraber, bir asırdan faz. la bir zamandır tatbik edilmemektedir $(80)$.

Ölüm cezasının tatbik sahasında vuku bulan bu istihalelerle birlikte infaz şeklinde de değişiklikler olmuş, işkenceli ölümlere zamanla nihayet verilmiş ve, ölüm cezası sadece hükümlünün hayatının izalesine inhisar ettirilmiştir. Hükümlünün hayatının izalesinde, dünyanın muhteliı memleketlerinde başka başka usullere müracaat edilmektedir. Fransada Guillotine adı verilen âletle ölüm cezası mahkûmlannın başı kesilmektedir. İngilterede, İspanyada Ittalyada ve daha başka birçok Avrupa memleketleri ile şark memleketlerinde ölüm cezasına mahkûm olanlar asılmaktadırlar. Almanyada, harpten önce, ölüm cezası mahkûmlarının başları balta ile kesilmekte idi. Nasyonal sosyalizm sırasında gaz hücreleriyle boğmak usulü tatbik edilmiştir. Şimdi ise ölüm cezası, bizde olduğu gibi asmak suretiyle infaz edilmektedir. Amerika birleşik devletlerinden baz!. larında, bu ceza, mahkûmun elektrikli sandalyede öldürülmesi suretiyle tatbik edilmektedir. Missouri, Nevada, Oklahoma gibi diğer bazı Birleşik Amerika Devletlerinde ise ölüm cezasina mahkûm olanlar, gaz hücrelerinde boğulmak suretiyle öldürülmektedirler (81).

\section{III. ÖLÜM CEZASININ LEH VE ALEYHINDEKI MUUTALAALAR}

Ölüm cezasının meşruiyeti meselesinin tarihçesine göz gezdirirken gördüğümüz gibi, bu cezasının leh ve aleyhinde bir çok mütalâlar ileri sürülmüștür. Başlangıçta, Ölüm cezası meselesi, yine evvelce verdiğimiz izahattan anlaşılacağı gibi, tamamen felsefî bir mesele olarak ortaya atılmıştır: Ölüm cezasının "meşru" olup olmadiğı araştırılmak istenmiş ve muhtelif mütalâalar ileri sürülerek bu cèzanın "meşru" olduğu veya olmadığı gösterilmeğe çalışılmıştır. Denmiştir ki insana hayatı cemiyet vermemiştir ki almağa hakkı olsun (82) Ölüm cezası aleyhtarlanın bu iddialarına karṣı, ölüm cezasına taraftar olanlar,

(80) Bk. Rev. Sci. Crim, 1949, s. 181 1953.

(81) Bk. Ölüm cezaları nasıl tatbik edilmelidir, Yeni Istanbul $20 \mathrm{kasım}$

(82) Kars. Kunter, Ölüm cezası ilga edilmeli mi, edilmemeli mi? Cumhuriyet. 21.2 .1955

(83) Ölüm cezasının "meşru" olup olmadığı hakkında ileri sürülen diğex mülâhazalar için, Montesquieu, J. - J. Rousseau ve Beccaria'nın ölüm cezası hakkında, yukarıda izah edilen, fikirlerine bakınız. 
insan için cemiyetin mevcudiyetine zaruret bulunduğuna göre, cemiyetin, kendi mevcudiyet ve nizamm muhafaza edebilmesi için zarurî bulunan her türlü tedbirleri almağa "hakkı" olduğunu, zaten hürriyeti de insana cemiyet vermemiş olduğu halde kimsenin aklına cemiyetin, gerek. tiği zaman hürriyeti bağlayıcı cezalar vermek "hakkı" bulunduğunu inkâr etmek gelmediği gibi eğer cemiyetin ölüm cezası vermek hakkı bu. lunmadığı kabul edilecek olursa hiç bir ceza vermek hakkı bulunmad ğ i- $^{-}$ nın da kabul edilmesi icab edeceğini ileri sürmüşler, ve kangren olmuş bir uzvu, bu hastalığın diğer uzuvlara da sirayetine mani olmak için, kesip atmakta tereddüt etmemek lâzım geldiğini iddia etmișlerdir (83).

Ölüm cezasının ilga edilip edilmemesi gerektiğinin bu cezanın meșru olup olmaması keyfiyeti ile halledilmek istenmesi o derece yayılmıştır ki, bazen ölüm cezasının ilgası meselesi bu cezanın meşruiyeti meselesi ile karıştınlmaktadır ${ }^{(84)}$. Halbuki mesele bu, şekilde vazedilince halli mümkün olmadığ 1 gibi, positivist mektep tarafından cezanın gayesi olarak, kefaret esası yerine, cemiyetin müdafaası esası ikame edildiğinden beri artık meselenin bu sekilde vazedilmesi de kabil değildir: Filhakika Devletin ceza verebileceği ve cezanın gayesinin de cemiyetin müdafaas! olduğu kabul edilince, bu gayeye ulaşmağa hizmet ettiği takdirde, ölüm cezasının diğer cezalar gibi tatbik edilebilmesi icap eder. Görülüyor ki ölüm cezasının tatbik edilip edilmemesi, ilgası icap edip etmediği meselesinin halli bu cezanın, cemiyetin müdafaasına hizmet edip etmiyece $\breve{s}$ hususunun tayinine bağh kalmakta, ölüm cezası ilga edilmeli mi, edilmemeli mi meselesi, ölüm cezası cemiyetin müdafaası için lüzumlu mudur, değil midir ? meselesine müncer olmaktadır.

Hemen şunu söyleyelim ki "ölüm cezası” aynı zamanda (hiç değil. se medenî memleketlerde) hissî bir mesele teşkil eder. Bu keyfiyet hêr ne kadar "ölüm cezası ilga edilmeli midir edilmemeli midir" meselesinın şu veya bu surette halledilmesinde rol oynamaz ise de, ölüm cezasının, cemiyetin müdafaası için zarurî olup olmadığının tesbitini gerekli kılmaktadır.

Filhakika "ölüm” hakkındaki düşünceler - hiç değilse bazı memleketlerde- bu gün, tamamiyle değişmiş bulunmaktadır. Artık ölüm, bi: aralık sayılabilmiş olduğu gibi, (yine hiç değilse bir kısım kimseler tarafından) bir "kurtuluş" olarak sayılmaktan çıkmıştır. Buna mukabil "hayatın, yaşamanın güzellikleri üzerinde israr edilmeğe başlanmıștır" (85).

(84) Bk. E. A. Müstecaplıoğlu, Ôp. cit., loc. cit.,

(85) Bk. Léautaud, Sartre, Guareschi. 
Ölümden sonrası artık, bir zamanlar bilindiği kadar iyi bilinmekten çımıştır. Bugün hiç değilse bazı kimseler, bir kimseyi öldürmekle o kimseyi ne yapmış olabilecekleri düşünmekte olup, bir ara inanıldığı gibi, o kimsenin yaptığı "fenalık" tan dolayı ölmekle bu fenalığın "cezasını çektiọ̆ı" nden ve bu suretle temize çıkıp ebedî hayata kavuşmak v.s. gibi avantajlar sağladığından şüphe etmektedirler. İşte "ölüm" üzerinde fikirlerde husule gelen bu değişiklik, yukanda söylediğimiz gibi, "ölüm cezasının" cemiyetin korunması için "zarurì" bulunup bulunmadığının araşt:nlmasmı gerekli kılmaktadır.

Ölüm cezasının, cemiyetin müdafaası için lüzumlu ve faydalı ol du ğu hususunda ileri sürülen fikirleri şöylece hülâsa edebiliriz (86):

A) Ölüm cezası, suçluyu mutlak surette cemiyetten uzaklaştınr. Günün birinde affedileceği, ce ${ }^{z a}$ evinden kaçabileceği gibi, ceza korkı-sunu azaltan ümitlerin önüne geçer.

B) Şiddetí çok büyük olduğuna ve ölüm korkusu kadar insan üzerine tesir yapabilecek diğer bir amil mevcut olmamasına göre müstak sel suçlulan ürkütmek bakımından tesiri büyüktür.

C) Bazı kimseler vardır ki suç bunlarn bünye ve yapılışlanının zэrurî bir neticesidir. Bu kimselerin islâhı imkânı mevcut değildir veyahut artık kalmamıştır. Bu gibi kimseler nasıl olsa suç işleyeceklerdir. Bunları sslah etmek değil, ancak zarar vermiyecek duruma getirmek bahis mevzuu olabilir. Islâhı mümkün olmayan bu kimselerin ölünceye kadar hapishanelerde bes'enmesi ve bunlann masraflannm dürüst ve namuslu vatandaşlara vükletilmesi de doğru olmayacağına göre bu gibi kimselerin ifnası gerektir ( $\left.{ }^{87}\right)$.

Bu mütalâlara verilen cevaplan ve, umumiyetle, ölüm cezasının cemiyet'n müdafaası için lüzumlu bulunmadığı hakkında ileri sürülen fikırleri de şöylece hülâsa etmek mümkündür (88).

A) Ölüm cezasının suçlan önleme tesiri müsbet olarak hiç bir zaman tesbit edilememistir. Eğer bu cezanın mevcut olduğu bir memlekette, deneme maksadiyle bu ceza muayyen bir zaman için (meselâ beş veya on sene) kaldırılmıs ve bu müddet zarfında suçlanın çoğalmış olduğu anlaşılmış olsa idi, ölüm cezasının, hakikaten, suçlan önlediği netice-

(86) Bk. Erem, Adalet Psikolojisi, 1950, s. 217

(87) Kars. Kunter, S. G. Makale, Cumhuriyet, 21.2.1955.

(88) Bk. Erem, op. cit., s. 217

(89) Bk. Erem, op. cit., s. 217 
sine vanlabilirdi ( $\left.{ }^{89}\right)$. Bu yapılmadığı için, ölüm cezasından korkarak suç işlemiyenlerin sayısı tesbit edilememekte, sadece, ölüm cezasından korkarak bir takım kimselerin suç işlemekten çekinečkleri tahmin $\epsilon$ dilmektedir.

B) Ölüm cezasının suçları önleme tesiri yoktur. Çünkü suçu işlediği esnada cezayı düşünsn sadece adi suçları işleyen kimselerdir. Büyük suç faillerinin suçu işlerken sonunu düşünmedikleri kendi ifadeleriyle sabit olmuştur. Zaten suçu işlerken her suçlunun içinde cezadan kurtulacağı ümidi vardır. Bu ümit cezanın her türlü önleyici tesirine mani olur. Cezanın şiddetini değ:i! , her suç işleyenin mutlaka ceza göreceğini müstak. bel suçlulara telkin etmek ve bunu fiilen göstermek lâzımdır ki suçlar önlenebilsin.

Ölüm cezasının diğer cezalara nisbetle ağır bir ceza olduğu katiyetle isbat edilemez. Hatta bütün ömrünce mahpus olarak kalmaktansa ölümü tercih edenler mevcuttur. Cezaevlerindeki "intihar" vakaları hüıriyeti bağlayıcı cezalarn ölümden daha ağır olduğunu gösterebilir. Ölüm cezasında korkutucu ve önleyici bir hassa mevcut olsa idi idam sahnesine șahit olan kimsenin ölüm cezasını müstelzim bir suç işlememesi lầzım gelirdi. Halbuki İngiliz Parlâmentosuna verilen bir rapora göre 167 ölüm mahkûmundan 121 tanesi son dakikalarnı birlikte geçirdikleri cẹza evi rahibine başkasının idamında hazır bulunduklarıı söylemişstir.

Ayrıca, ölüm cezasının tamiri kabil olmaması, bölünmek ve derecelendirilmek suretiyle suçluya uydurulması imkânı bulunmaması keyfiyetleri ileri sürülerek bu ceza, ceza infaz ilmi bakımından da tenkid edilmekte ise de bu tenkidlere, ölüm cezası verilirken çok dikkatli davranıldığı, zaten fliğer cezaların da tamirinin kabil olmadığı, yine diğer cezalann ve bilhassa müebbet cezaların da derecelendirilmeleri imkânı bulunmadı̌̆ı ileri sürülmek suretiyle cevap vermek mümkündür $\left({ }^{90}\right)$.

Ölüm cezasını cemiyetin müdafaası bakımından leh ve aleyhinde ileri sürülen fikirlerden şu neticeyi çkarabiliriz:

Ölüm cezasının korkutucu ve suçları önleyici tesiri- bilhassa bu cezanın korkudan ziyade, yukanda işaret ettiğimiz hissi bir takım mülâhłazalarła tiksinti uyandırdığı memleketlerde- şüpheli olup, bunlara isłınaden ölüm cezasının, cemiyetin müdafaası için lüzumlu bulunduğu "müsbet" bir şekilde iddia edilemez.

(90) Bk. Kunter, S. G. Makale, loc. cit., 
Ölüm cezasının cemiyetin korunmasına hizmet ettiği hususundakì en ciddi mütalâa, Ferrinin dediği gibi, ölüm cezasının tek mantıki dayanağı, halk arasında canavar adı verilen ve yapılışlan iktizası suç işledikleri kabul edilen kimselere karșı cemiyeti müessir bir şekilde korumak için bu gibi kimselerin ifnası gerektiğidir.

İslâhı kabil olmayan doğuştan suçluların öldürülmesi fikri tabii slarak akla gelen bir fikirdir. Fakat, "suçlunun cezalandırılmak icap eden bir kimse değil, yok edilmesi gereken bir kimse olduğu şeklinde" de ifade edilebilecek ( ${ }^{91}$ ), bu fikri ihtiyatla karşlamak ve umumileştirmekten kaçınmak da icabeder. Filhakika, bazı kimselerin cemiyet için tehlikeli olduklanı, bunlanın ıslâhı imkânı bulunmadığı ve yok edilmeleri icap ettiği kabul edilence, cemiyetin kötülerden ayıklanması, tedavisi kabil olmayan hastalardan, sakatlardan ve ilh dahi cemiyetin kurtanlması iâzım geldiğinin kabulüne de mâni kalmamaktadır.

Görülüyor ki cemiyetin, ölüm cezasiyle korunması fikri, cemiyetin, sun'î bir ıstfaya tabi tutulması fikrine müncer olmaktadır (92).

(91) Bk. Diderot, lettre à Landois, Graven, op. cit., loc. cit., s. 37 den naklen

(92) Bu hususta Bk. Ferri, Tarde ve Graven, op. cit., loc. cit., s. 36 ve son 